\title{
DÜBLIN
}

Technological University Dublin

ARROW@TU Dublin

2018-04-25

\section{Emerging Technologies for the Pretreatment of Lignocellulosic Biomass}

\author{
Shady S. Hassan \\ Technological University Dublin, shady.hassan@mydit.ie \\ Gwilym Williams \\ Technological University Dublin, gwilym.williams@tudublin.ie \\ Amit Jaiswal \\ Technological University Dublin, amit.jaiswal@tudublin.ie
}

Follow this and additional works at: https://arrow.tudublin.ie/tfschafart

Part of the Bioresource and Agricultural Engineering Commons

\section{Recommended Citation}

Hassan, S. S., Williams, G. A. \& Jaiswal, A. K. (2018). Emerging technologies for the pretreatment of lignocellulosic biomass. Bioresource Technology, 262, pp.310-318. doi: 10.1016/j.biortech.2018.04.099

This Review is brought to you for free and open access by the School of Culinary Arts and Food Technology at ARROW@TU Dublin. It has been accepted for inclusion in Articles by an authorized administrator of ARROW@TU

Dublin. For more information, please contact

arrow.admin@tudublin.ie, aisling.coyne@tudublin.ie, gerard.connolly@tudublin.ie.

Funder: Technological University Dublin (DIT)

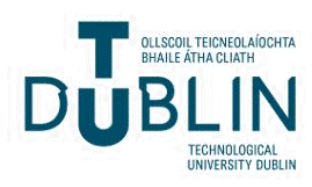




\section{Accepted Manuscript}

Review

Emerging Technologies for the Pretreatment of Lignocellulosic Biomass

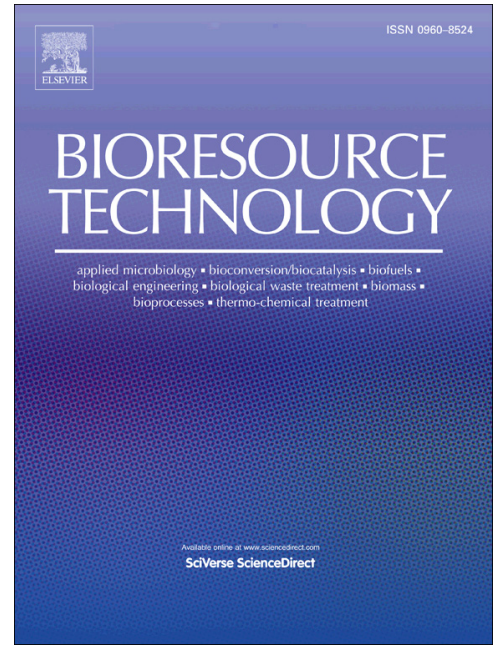

Shady S. Hassan, Gwilym A. Williams, Amit K. Jaiswal

PII:

S0960-8524(18)30622-9

DOI:

https://doi.org/10.1016/j.biortech.2018.04.099

Reference:

BITE 19879

To appear in:

Bioresource Technology

Received Date:

23 March 2018

Revised Date:

23 April 2018

Accepted Date:

24 April 2018

Please cite this article as: Hassan, S.S., Williams, G.A., Jaiswal, A.K., Emerging Technologies for the Pretreatment of Lignocellulosic Biomass, Bioresource Technology (2018), doi: https://doi.org/10.1016/j.biortech.2018.04.099

This is a PDF file of an unedited manuscript that has been accepted for publication. As a service to our customers we are providing this early version of the manuscript. The manuscript will undergo copyediting, typesetting, and review of the resulting proof before it is published in its final form. Please note that during the production process errors may be discovered which could affect the content, and all legal disclaimers that apply to the journal pertain. 


\section{Emerging Technologies for the Pretreatment of Lignocellulosic Biomass}

Shady S. Hassan ${ }^{1,2}$, Gwilym A. Williams ${ }^{2}$ and Amit K. Jaiswal ${ }^{1 *}$

${ }^{1}$ School of Food Science and Environmental Health, College of Sciences and Health, Dublin Institute of Technology, Cathal Brugha Street, Dublin 1, Republic of Ireland.

${ }^{2}$ School of Biological Sciences, College of Sciences and Health, Dublin Institute of Technology, Kevin Street, Dublin 8, Republic of Ireland.

*Corresponding author:

Email: amit.jaiswal@dit.ie; akjaiswal@outlook.com

Tel: +35314024547 


\begin{abstract}
Pretreatment of lignocellulosic biomass to overcome its intrinsic recalcitrant nature prior to the production of valuable chemicals has been studied for nearly 200 years. Research has targeted eco-friendly, economical and time-effective solutions, together with a simplified large-scale operational approach. Commonly used pretreatment methods, such as chemical, physico-chemical and biological techniques are still insufficient to meet optimal industrial production requirements in a sustainable way. Recently, advances in applied chemistry approaches conducted under extreme and non-classical conditions has led to possible commercial solutions in the marketplace (e.g. High hydrostatic pressure, High pressure homogenizer, Microwave, Ultrasound technologies). These new industrial technologies are promising candidates as sustainable green pretreatment solutions for lignocellulosic biomass utilization in a large scale biorefinery. This article reviews the application of selected emerging technologies such as ionizing and non-ionizing radiation, pulsed electrical field, ultrasound and high pressure as promising technologies in the valorization of lignocellulosic biomass.
\end{abstract}

Keywords: Lignocellulose; pretreatment; green technology; emerging technology; advanced biorefinery.

Abbreviations: LC, lignocellulose; MW, microwaves; US, ultrasound; HHP, high hydrostatic pressure; HPH, high pressure homogenization; UHPH, ultra-high pressure homogenization; PEF, pulsed-electric field; EB, electron beam. 


\section{Introduction}

Since the industrial revolution 250 years ago, the world has pursued a linear economic model of "take, make \& dispose" that was built on the presumption of plentiful and inexpensive natural resources. Contrasting with this approach, the new "Bioeconomy" economic model of the 21 st century encourages the reuse and recovery of resources, instead of the mere use of natural non-renewable resources, in order to achieve economic prosperity and ecological survival. In this context, the biorefinery is the economic engine propelling society to achieve a sustainable economy by conversion of the abundantly available, renewable and non-edible lignocellulosic biomass, such as agricultural residue and food industry waste, into usuable energy, fuels and chemicals.

However, due to the complex hierarchical structure and recalcitrant nature of lignocellulosic biomass, pretreatment steps present the most critical challenge to biomass utilization prior to conversion. The principal treatment regimes available for lignocellulosic biomass pretreatment may be categorized as biological, chemical, physical or physicochemical approaches (Kumar and Sharma, 2017). Generally, currently used pretreatment approaches suffer significant disadvantages in the goal to achieve cost effective, industrial scale, ecofriendly production.

The harsh chemicals and high conventional heating methods used for biomass pretreatment require extensive amounts of energy and are not environmentally friendly. Furthermore, these pretreatment strategies lead to the formation of numerous undesirable compounds, such as aliphatic acids, vanillic acid, uronic acid, 4-hydroxybenzoic acid, phenol, furaldehydes, cinnamaldehyde, and formaldehyde, which may all interfere with the growth of the fermentative microorganisms during fermentation (Ravindran and Jaiswal, 2016). This encouraged the movement from non-sustainable conventional pretreatments (e.g. chemical 
and physiochemical pretreatments) to sustainable green pretreatments (e.g. biological pretreatments). However, long treatment times, low yields and loss of carbohydrate during pretreatment are considered to be the major challenges in biological pretreatment by microorganisms (Saha et al., 2016). Furthermore, pretreatment processes can cost more than $40 \%$ of the total processing cost, and represent the most energy intensive aspects in biomass conversion to value added products (Sindhu et al., 2016). Thus, the challenge of low efficiency production associated with green pretreatments encouraged the investigation of using large scale technologies that are now available on the market as scalable green pretreatments to achieve sustainable and efficient pretreatment process of lignocellulosic biomass.

In recent years, advances in applied research within the field of chemistry, and featuring extreme and non-classical conditions, has led to the development of novel food processing technologies that are now available on a commercial scale. Interestingly, some of these technologies hold promise as green approaches for the pretreatment of lignocelluosic biomass, with possible advantages of lower cost and higher productivity within the context of a commercial-scale biorefinery. Numerous articles have reviewed common biomass pretreatment methods (Chen et al., 2017; Kumar and Sharma, 2017), green technologies (Capolupo and Faraco, 2016), and emerging technologies (Singh et al., 2016). However, a review of all emerging pretreatment technologies is missing in the current literature. This article reviews the application of selected emerging technologies for pretreatment of lignocelluosic biomass, including non-ionizing radiation (microwaves), ionizing radiation (gamma ray, electron beam), pulsed-electric field, high pressure (high hydrostatic pressure, high pressure homogenization) and ultrasound. 


\section{Lignocellulosic biomass}

Lignocellulosic biomass refers to plant biomass that can be divided into four categories: hardwood, softwood, agricultural wastes and grasses. Interestingly, agricultural residues are being produced in very large amounts (billions of tons) each year around the world, but the majority of these residues are either discarded or burned. Food waste is defined as any discarded food (including inedible parts), removed from the food supply chain and which may be either recovered for alternative use or disposed (including composted, crops ploughed in/not harvested, anaerobic digestion, bio-energy production, co-generation, incineration, disposal to sewer, landfill or discarded to sea) (Östergren et al., 2014). In the EU-28 countries, it is estimated that an average of 9 to $10 \mathrm{~kg}$ of waste is generated for every tonne of food in the primary production sector, while an average of $22 \mathrm{~kg}$ of food waste is generated for every tonne in the food processing sector (Stenmarck et al., 2016). The latter EU figures do not include by-products destined for animal feed and bio-based products. Lignocellulosic wastes generated from agriculture and food processing can be utilized as feedstock for the second generation of sustainable biorefineries.

Plant biomass is composed mainly of polysaccharides (cellulose, hemicellulose) and lignin. Polysaccharides are polymers of sugars and therefore a potential source of fermentable sugars, while lignin can be used for the production of chemicals. Generally, cereal residues

(e.g. rice straw, wheat straw, corn stover, and sugarcane bagasse) contain a large fraction of lignocellulose substances and represent the favourite feedstock for biorefineries, while grasses, fruit and vegetable wastes have less lignocellulosic content.

The ECN Phyllis2 database (www.phyllis.nl) is an open literature facility which is readily available to users and documents the composition of biomass and waste. Furthermore, table 1 shows the chemical composition of different lignocellulosic feedstocks based on recent 
literatures published in 2016, 2017 and 2018. Biomass on a dry weight basis generally contains cellulose $(50 \%)$, hemicellulose $(10-30 \%$ in woods, or $20-40 \%$ in herbaceous biomass) and lignin (20-40\% in woods or 10-40\% in herbaceous biomass) (Sharma et al., 2015). However, these ratios between cellulose, hemicellulose and lignin within a single plant will vary with different factors like age, harvesting season and culture conditions.

Pretreatment of lignocellulosic biomass is a necessary step to convert biomass into fermentable sugars and to enable enzymatic hydrolysis to break the lignin and hemicellulose structures and to free the buried cellulose (Sun et al., 2016). Pretreatment steps should be simple, eco-friendly, cost-effective and economically feasible (Ravindran et al., 2018). In addition, the pretreatment process should not give rise to inhibitory compounds or loss in the fraction of interest (polysaccharide or lignin). Moreover, to date, there is no harmonised pretreatment strategy to suit all types of lignocellulosic biomass, and the pretreatment process depends mostly on the type of lignocellulosic biomass and the desired products. However, the use of a combination of two or more pretreatment strategies can significantly increase the efficiency of the process, and represents an emerging approach in this field of study.

\section{Conventional approaches for pretreatment of lignocellulosic biomass}

Generally, each of the common pretreatment approaches that fall under the four categories of physical, chemical, physio-chemical and biological methods work differently to break the complex structure of the lignocellulosic material. As a result, different products and yields can be obtained from each pretreatment approach, and each method has its advantages and disadvantages that are summarized in Table 2. While some of the methods listed have successfully made the transition from research platform to the industrial stage, significant challenges remain, including in some cases the generation of environmentally hazardous 
wastes and/or high energy inputs; there is a pressing need for green technology solutions to this challenge (Capolupo and Faraco, 2016).

\section{Green approaches for pretreatment of lignocellulosic biomass}

In recent years, the concept of "Green Chemistry" has gained increasing interest as a possible approach to the challenge of developing a viable biorefinery concept. Central to achieving this goal is the development of technology that uses raw materials more efficiently, eliminates waste and avoids the use of toxic and hazardous materials. Selected green methods currently being pursued for pretreatment of lignocellulosic biomass are summarised in Table 3. Although these green methods are environmentally friendly, problems exist regarding high production costs and poor efficiency, as well as lack of availability of commercial equipment suited to industrial scale processing. However, the more widespread adoption of such technology by the food industry, with anticipated decreases in initial capital cost and increased scale of operation, may encourage uptake for pretreatment of lignocellulosic biomass.

\section{Emerging technologies for pretreatment of Lignocellulosic biomass}

Chemical approaches conducted under extreme or non-classical conditions are currently a dynamically developing area in minimal food processing. Microwaves, ultrasound, gamma ray, electron beam, pulsed-electric field, high hydrostatic pressure, and high pressure homogenization are non-thermal food processing technologies that also being investigated for pretreatment of lignocellulosic biomass. 


\subsection{Microwave Irradiation}

Microwaves are an electromagnetic radiation with wavelengths ranging from $1 \mathrm{~mm}$ to $1 \mathrm{~m}$. They are located between 300 and $300,000 \mathrm{MHz}$ on the electromagnetic spectrum and are a nonionizing radiation that transfers energy selectively to different substances (Huang et al., 2016a). Microwaves have attracted renewed interest since the 1980s, when Gedye et al. (1986) reported the increase of hydrolysis, oxidation, alkylation and esterification processes by energy efficient microwave heating. Researchers have reported good lignocellulosic pretreatment performance using microwave radiation over the past 30 years, and have gradually moved from laboratory to pilot scale (Li et al., 2016a). Currently, microwaveassisted pretreatment technologies of lignocellulosic biomass can be classified into two main groups: (a) Microwave-assisted solvolysis under mild temperatures $\left(<200{ }^{\circ} \mathrm{C}\right)$ that depolymerises the biomass to produce value-added chemicals, and (b) Microwave-assisted pyrolysis of lignin without oxygen, under high temperatures $\left(>400{ }^{\circ} \mathrm{C}\right)$ to convert biomass to bio-oil or bio-gases. Each of the two groups of technologies might be accomplished with catalysts. However, microwave-assisted pyrolysis is discussed largely due to energy shortage and sustainability plans of most of the Countries.

Compared with conventional heating, microwave radiation has significant advantages such as: (a) fast heat transfer, short reaction time, (b) selectivity and uniform volumetric heating performance (c) easy operation and energy efficient and (d) low degradation or formation of side products. In addition, microwave hydrothermal pretreatment removes more acetyl groups in hemicellulose, which may be raised from the hot spot effect of microwave irradiation (Dai et al., 2017).

In the case of conventional heating, energy is transferred from the outside surface of the material inwards to the core of the material by conduction. Thus, overheating can occur on 
the outside surface whilst still maintaining a cooler inner region. Contrasting with this, microwaves induce heat at the molecular level by direct conversion of the electromagnetic energy into heat. Energy is therefore uniformly dissipated throughout the material.

Materials can be grouped into three categories according to their response to microwaves: insulators, absorbers, and conductors. Insulators are materials which are transparent to microwaves (e.g., glass and ceramics), conductors are materials which show high conductivity and thus reflect microwaves from the surface (e.g., metals), while absorbers or dielectrics are materials that can absorb microwaves and convert microwave energy into heat (Huang et al., 2016b). Most biomass is generally considered as low lossy materials, and they need to be supported with materials that achieve rapid heating, such as graphite, charcoal, activated carbons and pyrites.

Interestingly, Salema et al. (2017) studied the dielectric properties of different biomass from agriculture and wood-based industries (including oil palm shell, empty fruit bunch, coconut shell, rice husk, and sawdust) and reported that all were low loss dielectric materials. Such materials do not absorb microwaves well during microwave-assisted pyrolysis until the char is formed, and the microwave absorption will then be significantly higher.

\subsubsection{Microwave-assisted solvolysis (pretreatment of lignocellulosic biomass)}

In conventional heating methods, the lignocellulosic biomass is ground into small particles to prevent large temperature gradients and then heated by indirect heat conduction or high pressure steam injection up to $160-250{ }^{\circ} \mathrm{C}$. Therefore, fermentable sugar recovery and conversion might be affected by degradation of the hemicellulose into furfural or humic acids (Li et al., 2016a). Alternatively, microwave heating is reported to enhance enzymatic 
saccharification through fibre swelling and fragmentation (Diaz et al., 2015) as a result of the internal uniform and rapid heating of large biomass particles. Almost no effect is observed in plant fibre material when treated with microwaves under temperatures that are equal to or below $100{ }^{\circ} \mathrm{C}$ (Chen et al., 2017).

The performance of microwaves depends on the dielectric properties of biomass which represent the ability of the material to store electromagnetic energy and to convert this energy into heat. Although, biomass usually is a low microwave absorber, the presence of relatively high moisture and inorganic substances can improve the absorption capacity of biomass (Li et al., 2016b). The increasing commercial availability of flow-through microwave systems may be of particular relevance to lignocellulosic pretreatment.

Choudhary et al. (2012) evaluated the pretreatment of sweet sorghum bagasse (SSB) biomass through microwave radiation, and reported that about $65 \%$ of maximal total sugars were recovered when $1 \mathrm{~g}$ of SSB in $10 \mathrm{ml}$ water was subjected to $1000 \mathrm{~W}$ for 4 minutes. Scanning electron microscope analysis of microwave-assisted pretreatment of corn straw and rice husk in alkaline glycerol showed clear disruption of the plant cell structure (Diaz et al., 2015). Recently, Ravindran et al. (2018) reported that microwave-assisted alkali pretreatment was the best pretreatment method for brewers' spent grain (1g of BSG in $10 \mathrm{ml} 0.5 \% \mathrm{NaOH}$ was pretreated using $400 \mathrm{~W}$ for 60 seconds), as compared with dilute acid hydrolysis, steam explosion, ammonia fiber explosion, organosolv and ferric chloride pretreatment. The authors found that BSG after microwave-assisted alkali pretreatment yielded $228.25 \mathrm{mg}$ of reducing sugar/g of BSG which was 2.86-fold higher compared to untreated BSG $(79.67 \mathrm{mg} / \mathrm{g}$ of BSG). Others have also found that microwave radiation for lignocellulosic pretreatment 
possesses the advantage of low capital cost, easy operation and significant energy efficiency (Kostas et al., 2017).

\subsubsection{Microwave-assisted pyrolysis of lignocellulosic biomass}

In this technique, microwave irradiation is used as a pretreatment method followed by biological conversion of biomass into biofuel, as well as a thermo-chemical pyrolysis of biomass. Pyrolysis is the conversion of biomass to liquid (bio-oil), solid (bio-char) and gaseous (syn-gas) fractions, by heating the biomass in the absence of air to high temperatures. Pyrolysis can convert the lignocellulosic biomass into biofuels or chemicals more completely and more quickly (Huang et al., 2016b). Microwave-assisted pyrolysis can convert fifty percent of lignocellulosic biomass processed into bioenergy gas products (Huang et al., 2015). Oil obtained from the fast pyrolysis of lignocellulosic materials contains a complex mixture of phenolic compounds derived primarily from lignin (Bu et al., 2011). Huang et al. (2016a) compared the heating rate of both microwave and conventional pyrolysis methods using the same input power level. They reported that the heating rate of microwave pyrolysis was higher by up to $42 \%$ when compared with the heating rate of conventional processes; this means that microwave pyrolysis requires less time to reach the target temperature, indicating superior performance over conventional heating.

When converting agricultural biomass to higher value products using pyrolysis, the process may be tailored to meet either qualitative or quantitative objectives, such as maximizing the yield of solids, liquids or gases, as well as improving the energy density of chars or producing good quality syngas for the synthesis of bio-based chemicals. Calculations of the Energy Return On Investment (EROI) for microwave pyrolysis by Lo et al. (2017) provided evidence for the energetic efficiency and economic feasibility of microwave pyrolysis of 
lignocellulosic biomass. The authors reported that when microwave pyrolysis is conducted on biomass feedstock (rice straw, rice husk, corn stover, sugarcane bagasse, bamboo leaves, sugarcane peel, or waste coffee grounds) with a heating value of $16 \mathrm{MJ} / \mathrm{kg}$ using microwave power of $500 \mathrm{~W}$ for $30 \mathrm{~min}$, the EROI was be approximately 3.56. This finding may support the feasibility of the process, considering that minimum EROI for sustainable society is 3.0 (Hall et al., 2009). EROI is the ratio of the energy supplied to society and the energy invested to capture and deliver that energy (Hall et al., 2013).

\subsection{Ultrasound}

Over 90 years ago, Wood and Loomis (1927) reported the effects of the ultrasonic treatment on cellular biomass, such as floc fragmentation, cell rupture and destruction. Ultrasound in the range of $20 \mathrm{kHz}$ to $1 \mathrm{MHz}$ is used in chemical processing, while higher frequencies are used in medical and diagnostic applications. Ultrasound pretreatment of biomass results in alteration of the surface structure and production of oxidizing radicals that chemically attack the lignocellulosic matrix (Luo et al., 2013). Additionally, ultrasound can disrupt $\alpha-\mathrm{O}-4$ and $\beta-O-4$ linkages in lignin (Shirkavand et al., 2016) which results in the splitting of structural polysaccharides and lignin fractions by formation of small cavitation bubbles (Kumar and Sharma, 2017). The bubbles formed grow to a certain critical size and then become unstable, collapsing violently, and achieving pressures up to 1,800 atmospheres and temperatures of 2,000-5,000 K (Kunaver et al., 2012). Hence, ultrasonic disruption may represent an effective green technology for the pretreatment of lignocellulosic biomass.

Kunaver et al. (2012) studied the utilization of forest wood wastes to produce valuable chemicals using high energy ultrasound at a power of $400 \mathrm{~W}$ and amplitudes ranging from $20 \%$ to $100 \%$, and reported shorter reaction times (by a factor of up to nine). Sun et al., 
(2004) reported that ultrasound irradiated sugarcane bagasse achieved 90\% hemicellulose and lignin removal at an ultrasound power of $100 \mathrm{~W}$ and sonication time for 2 hours in distilled water at $55^{\circ} \mathrm{C}$. The ultrasound was found to attack the integrity of cell walls, cleaving the ether linkages between lignin and hemicelluloses, and increasing the accessibility and extractability of the hemicelluloses. This is in agreement with another study for ultrasoundassisted alkaline pretreatment of sugarcane bagasse using $400 \mathrm{~W}$ microwave power for 47.42 minutes in $2.89 \% \mathrm{NaOH}$ and $70.15^{\circ} \mathrm{C}$, where the theoretical reducing sugar yield recovered was about $92 \%$ (Velmurugan, 2012).

Ultrasound-assisted, alkali pretreatment can enhance lignin degradation and enzymatic saccharification rates by breaking hydrogen bonds between molecules of lignocellulosics and lowering its crystallinity. However, the ultrasonic vibration energy is too low to change the surface conformation of the raw material biomass particles (Zhang et al., 2008). Subhedar et al. (2017) recently investigated the ultrasound-assisted delignification and enzymatic hydrolysis of three biomass types (groundnut shells, pistachio shell and coconut coir) and reported an approximate $80-100 \%$ increase in delignification over conventional alkali treatments, where biomass loading was $0.5 \%$, ultrasound power was $100 \mathrm{~W}$ and duty cycle was $80 \%$ for 70 minutes. Additionally, reducing sugar yields in the case of ultrasoundassisted enzymatic hydrolysis under optimised conditions of enzyme loading at $0.08 \% \mathrm{w} / \mathrm{v}$, substrate loading at $3.0 \% \mathrm{w} / \mathrm{v}$, ultrasound power of $60 \mathrm{~W}$ and duty cycle of $70 \%$ for $6.5 \mathrm{~h}$, were $21.3,18.4$ and $23.9 \mathrm{~g} / \mathrm{L}$ for groundnut shells, pistachio shells and coconut coir respectively, significantly more than that found for alkali hydrolysis $(10.2,8.1$ and $12.1 \mathrm{~g} / \mathrm{L})$. It was also reported that reducing sugar yield was increased by a factor of approximately 2.4 by the application of ultrasound at a power of $60 \mathrm{~W}$ and duty cycle of $70 \%$ for pretreatment of lignocellulosic waste paper at substrate loading of $3.0 \%(\mathrm{w} / \mathrm{v})$ and cellulase loading of 
$0.8 \%(\mathrm{w} / \mathrm{v})$ for 6.5 hours (Subhedar et al., 2015). Moreover, acoustic cavitation was found to successfully decrease the crystallinity of the microcrystalline cellulose, enabling enhanced enzymatic digestibility (Madison et al., 2017).

Combining ultrasound with ammonia pre-treatment of sugarcane bagasse (sonication time of 45 minutes in $400 \mathrm{w}$ power, $100 \%$ amplitude and $24 \mathrm{kHz}$ frequency, biomass loading of $1 \mathrm{~g}$ per $10 \mathrm{ml}$ of $10 \%$ ammonia and temperature of $80^{\circ} \mathrm{C}$ ) resulted in a cellulose recovery of 95.78\%, with 58.14\% delignification (Ramadoss and Muthukumar, 2014). Additionally, the synergistic effect of combining ammonia with ultrasound reduced by-product formation, enabled the treatment to be conducted at moderate temperature and reduced cellulose crystallinity. This is with an agreement with recent work carried out on ultrasound-assisted dilute aqueous ammonia (2.0\% w/v aqueous ammonia) pretreatment of corn cob, corn stover and sorghum stalk using ultrasound at $90 \mathrm{~W}$ power and $50 \mathrm{kHz}$ frequency (Xu et al., 2017); the highest enzymatic hydrolysis sugar yield was approximately $81 \%$ in corn cob $\left(70^{\circ} \mathrm{C}, 4 \mathrm{~h}\right)$, $66 \%$ in corn stover $\left(60^{\circ} \mathrm{C}, 2 \mathrm{~h}\right)$ and $57 \%$ in sorghum stalk $\left(50^{\circ} \mathrm{C}, 4 \mathrm{~h}\right)$. Similarly, pretreatment of spent coffee waste by ultrasound assisted potassium permanganate (biomass loading of $1.0 \mathrm{~g}$ at $10 \mathrm{ml}$ of $4 \% \mathrm{KMnO}_{4}$ for 20 minutes, ultrasonic frequency of $47 \mathrm{kHz}$ and power of $310 \mathrm{~W}$ ) resulted in $98 \%$ cellulose recovery and $46 \%$ lignin removal (Ravindran et al., 2017).

\subsubsection{Combination of Microwave and Ultrasound}

Both microwaves and ultrasound are energy that may be applied to biomass to reduce the size, increase the exposed surface area and increase availability of cellulose, hemicellulose and oligosaccharides present in the biomass, facilitating further processing to produce target chemicals (Dunson et al., 2006). Ultrasonication and microwave pretreatments were found to accelerate hydrolysis and biodegradability of agriculture wastes (grape pomace and olive 
pomace) and wastewater sludges used to produce biogas. The author concluded also that ultrasonication was found to be more effective pretreatment method than microwaves alone (Alagöz et al., 2016) . The applicability of the combination of microwaves with ultrasound for pretreatment of biomass has been considered in a number of patents (Olsen, 2011; Augustin et al., 2012; Gjermansen, 2014). Such a hybrid approach was found to selectively degrade waxes and lignin, and microwaves were reported to remove the waxy layer from the surface of biomass to increase the surface area available for enzymic action.

In hemicellulose degradation, the combination of ultrasound and microwave energy was found to provide a supplemental method of heating the biomass internally, which rapidly hydrolyzed the hemicellulose (North, 2016). Hydrothermal pretreatment of corncobs was also achieved using ultrasound (20 and $60 \mathrm{kHz}$ for 10 and 20 minutes respectively), and microwaves (400 w and $600 \mathrm{w}$ for 1 and 130 minutes respectively) to produce a high yield of xylose maize hydrolyzate core (Junli et al., 2016).

Most recently, patent inventors reported on the superimposed dual-energy of an ultrasound and microwave-assisted ionic liquid. A microwave power of 15 1000W (frequency of 1500 3000 MHz) combined with ultrasound (200 1000W and $15 \sim 30 \mathrm{KHz})$ effectively removed lignin, could enhance the efficiency of enzyme hydrolysis of cellulose, and significantly increased fermentable sugar (glucose and xylose) yield (Xing et al., 2017).

\subsection{Gamma ray}

Gamma ray radiation is obtained from radioisotopes (Cobalt-60 or Cesium-137) and has also been tested as a lignocellulosic pretreatment. Ionizing radiation can easily penetrate the 
lignocellulosic structure, causing modification of the lignin and a breakdown of cellulose crystal regions. The latter effect is facilitated by the formation of free radicals which decay quickly from the amorphous regions after the termination of radiation, while decay at a certain period from the crystalline regions also causes further degradation of the biomass (Hyun Hong et al., 2014).

Liu et al. (2015) studied the effect of $\gamma$-irradiation on the bioconversion efficiency of microcrystalline cellulose (MCC), as compared with other pretreatment methods (ionic liquids - ILs, acidic aqueous ionic liquids, $1 \% \mathrm{HCL}$, and $\left.1 \% \mathrm{H}_{2} \mathrm{SO}_{4}\right)$. They reported that the most effective irradiation dose (891 kGy) possessed almost the same efficiency of MCC bioconversion as ILs pretreatment, and higher than that of other tested pretreatment methods. As a promising pretreatment technology, numerous articles have demonstrated that $\gamma$ irradiation pretreatment can enhance enzymatic hydrolysis of lignocellulosic biomass (Li et al., 2016c; Liu et al., 2016; Zhou et al., 2016; Liu et al., 2017). Gamma irradiation of rapeseed straw at $1200 \mathrm{kGy}$ was found to induce a series of changes in the physical and chemical properties of the material. The latter included alteration of the linkage between the carbohydrates and lignin in the plant biomass, decreases in particle size, narrowing of the distribution range, increases in the specific surface area, and decreases in the thermal stability of the treated biomass (Zhang et al., 2016a).

\subsection{Electron beam (EB) irradiation}

EB ionising radiation is obtained from a linear accelerator. This pretreatment uses accelerated beams of electrons to irradiate lignocelluosic biomass in order to disrupt the structure of cell wall polymers (lignin, cellulose, hemicellulose) by such processes as production of free 
radicals, inducing cross-link formation or chain scission, decrystallization, and/or decreasing the degree of polymerization (Grabowski, 2015).

EB irradiation of sugar maple (at dosages up to $1000 \mathrm{kGy}$ ) was found to depolymerize cellulose and hemicellulose structures to varying degrees, and increased the yield of phenolics (Mante et al., 2014). Yang et al. (2015) reported that the optimal EB irradiation was $500 \mathrm{kGy}$ to treat Korean Miscanthus sinensis prior to enzymatic hydrolysis for fermentable sugar production. EB is mainly effective on depolymerizing cellulose, and so therefore there is a requirement for use in combination with other pretreatments, such as steam explosion or alkali, for hydrolyses of hemicellulose and lignin (Leskinen et al., 2017; Xiang et al., 2017).

\subsection{Pulsed-electric field}

Pulsed-electric field (PEF) processing uses a simple device without moving parts that treats plant biomass or bio-suspensions between two electrodes to voltage pulses, with an electrical field strength of $0.1-80 \mathrm{kV} / \mathrm{cm}$ for a very short time $\left(10^{-4}\right.$ and $\left.10^{-2} \mathrm{~s}\right)$. Under the effect of PEF, the biological membrane is disrupted and local structural changes occur which result in a loss of semi-permeability, allowing the passage of intracellular compounds to the surrounding solution (Barba et al., 2015). This also facilitates the entry of hydrolytic enzymes through the pores of the treated plant cell membrane (Kumar and Sharma, 2017). Kumar et al. (2011) found that pretreatment of lignocellulosic materials (wood chip and switchgrass) with 2000 pulses at field strength of $10 \mathrm{kV} / \mathrm{cm}$ could improve the cellulose hydrolysis for conversion to fuel and chemicals. 
PEF may contribute to delignification of lignocellulosic biomass (Janositz et al., 2011), and depending on the PEF parameters, cell wall structure may be variably affected (Cholet et al., 2014). Future work is needed to explain the effects of pulsed electric fields on lignocellulosic structures (Golberg et al., 2016).

\subsection{High hydrostatic pressure (HHP)}

High hydrostatic pressure (HHP) has been used for decades as a tool in the food industry for "non-thermal" Pasteurization that involves subjecting products to a high hydrostatic pressure (100-600 MPa) without a deterioration in product quality or compromising safety. The industrial application of HPP is currently successful in the United States, Europe and Japan for Pasteurization of food products. Initial capital and operating costs have been reduced due to innovative concepts introduced by different equipment manufacturers. HPP tolling is another option for manufacturers who otherwise would never have access to the technology because of equipment costs which are still relatively high.

HPP treatment is based on two fundamental principles: (a) pressure is distributed proportionally in all parts of a biomass, irrespective of its shape and size; and (b) pressure favours all structural reactions and changes that involve a decrease in volume. Although researchers do not often have to take changes in pressure into account, like temperature it is a thermodynamic parameter of any enzyme-catalyzed reaction. Pressure treatment has the advantage over thermal treatment in not being time/mass-dependent. Additionally, pressure also only affects hydrogen bonds, leaving covalent bonds untouched and thus reducing the processing time. In addition, pressure affects the activity of some enzymes by direct changes in enzyme structure, changes in the reaction mechanism and modifications to the physical properties of substrate (Eisenmenger and Reyes-De-Corcuera, 2009). 
Oliveira et al. (2012) reported that high hydrostatic pressure is a promising tool for the engineering of enzymatic reactions within lignocellulosic biomass to obtain products with tailored properties, as changing the pressure and the exposure time of high hydrostatic pressure during the pretreatment step can control the rate and the extent of enzymatic hydrolysis. The authors investigated the effect of hydrostatic pressures of $300-400 \mathrm{MPa}$ for 15-45 min on Eucalyptus globulus kraft pulp, and found a 5-10-fold increase in the initial hydrolysis rate of xylan by xylanase after this pretreatment. In 2013, Castañón-Rodríguez et al. used increasing HPP up to 400-800 MPa to pre-treat sugarcane bagasse, in combination with different concentrations of chemical compounds, and reported significant increases in the susceptibility of biomass to enzymatic hydrolysis and a rise in glucose concentrations. Results showed few cracks, tiny holes and some fragments flaked off from the compacted lignocellulosic structure by the HPP treatments at an optimally efficient pressure of $250 \mathrm{MPa}$.

It is reported also that hydrolytic performance of fungal cellulases on coconut husk biomass increased by a factor of 2 under pressurised conditions (Albuquerque et al., 2016). Results showed porous areas and rupturing on coconut fibres treated by pressure values of $300 \mathrm{MPa}$ for 30 minutes. HPP is a promising choice, not only for biomass pretreatment, but also for inducing hydrolytic enzymes stability and activation (Murao et al., 1992).

\subsection{High-pressure homogenization (HPH)}

HPH is a well-known mechanical method for cell disruption and recovery of intracellular bioproducts. The homogenizer is geared towards producing a homogenous size distribution of particles suspended in a liquid, by using a pressure pump to force the liquid through a specific valve to achieve homogenization. Depending on the operating pressure, the process 
is called high-pressure homogenization ( $\mathrm{HPH}$, up to 150-200 $\mathrm{MPa}$ ), or ultra-high pressure homogenization (UHPH, up to 350-400 MPa).

Jin et al. (2015a) pre-treated four different lignocellulosic materials (corn straw, grass clipping, pine sawdust, and catalpa sawdust) with HPH under $10 \mathrm{MPa}$ working pressure. The authors reported a decrease of biomass particle size and an increase in the accessible surface area for enzyme hydrolysis, which led to high reducing sugars yield. Compared with alkalineheat pretreatment of grass clippings, HPH pretreatment is a promising eco-friendly method for biogas production from lignocellulosic biomass, which can destroy the microstructure of lignocellulosic biomass to an "empty-inside" structure, accessible for enzyme attack without loss in hemicellulose (Jin et al., 2015b). Chen et al. (2010) found that sugarcane bagasse treated with HPH (100 MPa) resulted in a significant decrease in particle size and a disturbance in the microstructure of the biomass that increased accessible surface area by 3fold. This highly efficient, yet simple and green, mechanical homogenization has been used recently to isolate nano-fibrillated cellulose from lignocellulosic biomass (Saelee et al., 2016).

\section{Techno-economic feasibility}

Equipment based on emerging technologies are available in the market, and are used mainly in food processing industry. Example of these equipment includes: continuous flow microwaves (Advanced Microwave Technologies, United Kingdom), ultrasonic processors (Industrial Sonomechanics, United States), pulsed electric field systems (Pulsemaster, Netherlands), electron beam system (Pro-beam, Germany), and high pressure systems (Multivac, France).

Microwave use in chemical processing has been shown to be a technically and economically feasible alternative to conventional heating. Hasna (2011) evaluated the cost-benefit of using 
microwave drying in corrugated paperboard manufacturing as an alternative to conventional steam platens. It was concluded that the microwave capital cost ( $\$ 7000$ per $\mathrm{kW})$ could be offset against utilities and power savings (from $\$ 128.00$ to $\$ 38.00$ per hour), compared with conventional steam platens. Such savings were achievable in less than one year with an assumption that operation hours are 6000 per year. The author also reported additional benefits from using microwave drying in corrugated paperboard manufacturing, such as improved quality, reduced wastage, and minimum starch consumption. In a recent feasibility study on ginger processing to oleoresin, an ultrasound pretreatment step was introduced as a novel method to enhance extraction of chemical constituents from plant materials (Romis Consultants Ltd, 2017); however, the study did not focus on economics related to ultrasound specifically. A feasibility study in Egypt on using gamma rays for food preservation indicated that the cost of irradiation for one ton of frozen poultry was US $\$ 130.4$, smoked fish US \$78.2, spices \$ 260.1 and dried vegetable \$26. Economic analysis evaluation indicated that the average rate-of-return would be about $16.9 \%$ annually, with a payback period of about 6 years (Eldin et al., 2002). The feasibility and the economic impact of electron beam processing in chestnut fruits was evaluated by Lopes (2014), who reported a strong dependence on processed quantity per unit time and product costing. Puértolas et al. (2010) calculated the economic cost of the treatment of grape mass to improve the phenolic extraction for red wine fermentation using PEF, and reported that cost could be around 0.01 and $0.2 € /$ ton. However, the author reported that inactivation of wine spoilage microorganisms by PEF is not feasible and can increase production costs by $4.2-8.4 € /$ ton due to energy inputs needed. The cost of high pressure processing (HPP) in comparison with thermal pasteurization was estimated to be $10.7 \not / 1$ for processing $16,500,0001 /$ year $(3,000$ 1/h), which corresponds to 7-fold higher than thermal pasteurization (Sampedro et al., 2014). Generally, the economic feasibility of emerging technologies is limited by the high cost of 
capital investment for new equipment. For commercial application of the emerging technologies in pretreatment of lignocellulosic biomass further feasibility studies will be needed considering the complexities of biorefining process, inter-dependence of pretreatment processes and the economics related to the market of the finished product.

\section{Conclusion}

To date, sustainability, energy saving, capital cost minimization and downstream process efficiency are still challenges toward commercial scale pretreatment of lignocellulosic biomass. The tendency is thus to use energy efficient green technologies. Interestingly, green commercial innovations from food technology present promising opportunities. Different emerging technologies have been investigated for pretreatment of lignocellulosic biomass; however, capital cost is generally high, and comparative efficiency of these techniques on different lignocellulosic biomass is not available. Hence, further studies are needed to identify the most efficient emerging technology, as well as feasibility studies to evaluate the viability of using these technologies in a commercial biorefinery.

\section{Acknowledgement}

Authors would like to acknowledge the funding from Dublin Institute of Technology (DIT) under the Fiosraigh Scholarship programme, 2017.

\section{References}

1. Albuquerque, E.D., Torres, F.A.G., Fernandes, A.A.R., Fernandes, P.M.B., 2016. Combined effects of high hydrostatic pressure and specific fungal cellulase improve coconut husk hydrolysis. Process Biochem. 51, 1767-1775.

2. Álvarez, A., Cachero, S., González-Sánchez, C., Montejo-Bernardo, J., Pizarro, C., 
Bueno, J.L., 2018. Novel method for holocellulose analysis of non-woody biomass wastes. Carbohydrate Polymers. 189, 250-256.

3. Aylin Alagöz, B., Yenigün, O., Erdinçler, A., 2016. Ultrasound assisted biogas production from co-digestion of wastewater sludges and agricultural wastes: Comparison with microwave pre-treatment. Ultrason. Sonochem. 40, 193-200.

4. Augustin, M.A., Dumsday, G.J., Mawson, R., Melton, L.D., Oliver, C.M., 2012. Treatment of plant biomass. WO2012000035A1.

5. Barba, F.J., Parniakov, O., Pereira, S.A., Wiktor, A., Grimi, N., Boussetta, N., Saraiva, J.A., Raso, J., Martin-Belloso, O., Witrowa-Rajchert, D., Lebovka, N., Vorobiev, E., 2015. Current applications and new opportunities for the use of pulsed electric fields in food science and industry. Food Res. Int. 77, 773-798.

6. Bajpai, P., 2016. Pretreatment of lignocellulosic biomass for biofuel production. Springer Nature.

7. Bu, Q., Lei H., Ren S., Wang L., Holladay J., Zhang Q., Tang J., Ruan R., 2011. Phenol and phenolics from lignocellulosic biomass by catalytic microwave pyrolysis. Bioresour. Technol. 102, 7004-7007.

8. Capolupo, L., Faraco, V., 2016. Green methods of lignocellulose pretreatment for biorefinery development. Appl. Microbiol. Biotechnol. 100, 9451-9467.

9. Castañón-Rodríguez, J.F., Torrestiana-Sánchez, B., Montero-Lagunes, M., PortillaArias, J., De León, J.A.R., Aguilar-Uscanga, M.G., 2013. Using high pressure processing (HPP) to pretreat sugarcane bagasse. Carbohydr. Polym. 98, 1018-1024.

10. Chandel A., da Silva, S., 2013. Sustainable Degradation of Lignocellulosic Biomass Techniques, Applications and Commercialization. InTech. Rijeka.

11. Chen, W., Chen, Y., Yang, H., Xia, M., Li, K., Chen, X., Chen, H., 2017. Copyrolysis of lignocellulosic biomass and microalgae: Products characteristics and 
interaction effect. Bioresource Technology. 245A, 860-868.

12. Chen, D., Guo, Y., Huang, R., Lu, Q., Huang, J., 2010. Pretreatment by ultra-high pressure explosion with homogenizer facilitates cellulase digestion of sugarcane bagasses. Bioresour. Technol. 101, 5592-5600.

13. Chen, H., Liu, J., Chang, X., Chen, D., Xue, Y., Liu, P., Lin, H., Han, S., 2017. A review on the pretreatment of lignocellulose for high-value chemicals. Fuel Process. Technol. 160, 196-206.

14. Cholet, C., Delsart, C., Petrel, M., Gontier, E., Grimi, N., L'Hyvernay, A., Ghidossi, R., Vorobiev, E., Mietton-Peuchot, M., Gény, L., 2014. Structural and Biochemical Changes Induced by Pulsed Electric Field Treatments on Cabernet Sauvignon Grape Berry Skins: Impact on Cell Wall Total Tannins and Polysaccharides. J. Agric. Food Chem. 62, 2925-2934.

15. Choudhary, R., Umagiliyage, A.L., Liang, Y., Siddaramu, T., Haddock, J., Markevicius, G., 2012. Microwave pretreatment for enzymatic saccharification of sweet sorghum bagasse. Biomass and Bioenergy 39, 218-226.

16. Dai, L., He, C., Wang, Y., Liu, Y., Yu, Z., Zhou, Y., Fan, L., Duan, D., Ruan, R., 2017. Comparative study on microwave and conventional hydrothermal pretreatment of bamboo sawdust: Hydrochar properties and its pyrolysis behaviors. Energy Convers. Manag. 146, 1-7.

17. Daza Serna, L. V, Orrego Alzate, C.E., Alzate, C.A.C., 2016. Supercritical fluids as a green technology for the pretreatment of lignocellulosic biomass. Bioresource Technology. 199, 113-120.

18. De Caprariis, B., De Filippis, P., Petrullo, A., Scarsella, M., 2017. Hydrothermal liquefaction of biomass: Influence of temperature and biomass composition on the bio-oil production. Fuel. 208, 618-625. 
19. Devendra, P., Maurya, Ankit, S., Negi, S., 2015. An overview of key pretreatment processes for biological conversion of lignocellulosic biomass to bioethanol. Biotech. 6, 597-609.

20. Diaz, A.B., Moretti, M.M. de S., Bezerra-Bussoli, C., Carreira Nunes, C. da C., Blandino, A., da Silva, R., Gomes, E., 2015. Evaluation of microwave-assisted pretreatment of lignocellulosic biomass immersed in alkaline glycerol for fermentable sugars production. Bioresour. Technol. 185, 316-323. Dunson, J., Tucker, M., Elander, R., Hennessey, S., 2006. Treatment of biomass to obtain a target chemical. US20070031919 A1.

21. Duque, A., Manzanares, P., Ballesteros, M., 2017. Extrusion as a pretreatment for lignocellulosic biomass: Fundamentals and applications. Renewable Energy.. 114B, $1427-1441$.

22. Eisenmenger, M.J., Reyes-De-Corcuera, J.I., 2009. High pressure enhancement of enzymes: A review. Enzyme Microb. Technol. 45, 331-347.

23. Eldin, M., El-Fouly, Z., Karem, H.A., 2002. Commercial feasibility and evaluation of consumer acceptance for certain irradiated food products in Egypt, in: Study of the Impact of Food Irradiation on Preventing Losses: Experience in Africa. International Atomic Energy Agency, Austria.

24. Gedye, R., Smith, F., Westaway, K., Ali, H., Baldisera, L., Laberge, L., Rousell, J., 1986. The use of microwave ovens for rapid organic synthesis. Tetrahedron Lett. 27, $279-282$.

25. Golberg, A., Sack, M., Teissie, J., Pataro, G., Pliquett, U., Saulis, G., Stefan, T., Miklavcic, D., Vorobiev, E., Frey, W., 2016. Energy-efficient biomass processing with pulsed electric fields for bioeconomy and sustainable development. Biotechnol. Biofuels 9, 94. 
26. Grabowski, C., 2015. The Impact of Electron Beam Pretreatment on the Fermentation of Wood-based Sugars. SUNY College of Environmental Science and Forestry. Honors Theses. Paper 63.

27. Hall, C.A.S., Balogh, S., Murphy, D.J.R., 2009. What is the minimum EROI that a sustainable society must have? Energies 2, 25-47.

28. Hall, C.A.S., Lambert, J.G., Balogh, S.B., 2013. EROI of different fuels and the implications for society. Energy Policy 64, 141-152.

29. Hans Sejr Olsen, 2011. Biogas production process with enzymatic pre-treatment. WO2011092136A1.

30. Hasna, A.M., 2011. Microwave Processing Applications in Chemical Engineering: Cost Analysis. J. Appl. Sci. 11, 3613-3618.

31. Huang, Y.-F., Chiueh, P.-T., Kuan, W.-H., Lo, S.-L., 2016a. Microwave pyrolysis of lignocellulosic biomass: Heating performance and reaction kinetics. Energy. 100, $137-144$.

32. Huang, Y.-F., Chiueh, P.-T., Kuan, W.-H., Lo, S.-L., 2015. Effects of lignocellulosic composition and microwave power level on the gaseous product of microwave pyrolysis. Energy 89, 974-981.

33. Huang, Y.-F., Chiueh, P.-T., Lo, S.-L., 2016b. A review on microwave pyrolysis of lignocellulosic biomass. Sustainable Environment Research. 26, 103-109.

34. Hyun Hong, S., Taek Lee, J., Lee, S., Gon Wi, S., Ju Cho, E., Singh, S., Sik Lee, S., Yeoup Chung, B., 2014. Improved enzymatic hydrolysis of wheat straw by combined use of gamma ray and dilute acid for bioethanol production. Radiat. Phys. Chem. 94, $231-235$.

35. Janositz, A., Semrau, J., Knorr, D., 2011. Impact of Pulsed Electric Fields (PEF) on post- permeabilization processes in plant cells. Innov Food Sci Emerg Technol. 12, 
$269-274$.

36. Jönsson, L.J., Martín, C., 2016. Pretreatment of lignocellulose: Formation of inhibitory by-products and strategies for minimizing their effects. Bioresource Technology. 199, 103-112.

37. Jin, S., Zhang, G., Zhang, P., Fan, S., Li, F., 2015a. High-pressure homogenization pretreatment of four different lignocellulosic biomass for enhancing enzymatic digestibility. Bioresour. Technol. 181, 270-274.

38. Jin, S., Zhang, G., Zhang, P., Jin, L., Fan, S., Li, F., 2015b. Comparative study of high-pressure homogenization and alkaline-heat pretreatments for enhancing enzymatic hydrolysis and biogas production of grass clipping. Int. Biodeterior. Biodegradation 104, 477-481.

39. Junli, R., Huan, Y.Y., Runcang, S., Xuan, L.Q., Fu, L.C., 2016. Method for preparing xylose hydrolysis fluid through hydrothermal pretreatment of corncobs under control of trace alkali. CN106222312A.

40. Kim, H., Ahn, Y., Kwak, S.-Y., 2016. Comparing the influence of acetate and chloride anions on the structure of ionic liquid pretreated lignocellulosic biomass. Biomass and Bioenergy. 93, 243-253.

41. Khan, A.S., Man, Z., Bustam, M.A., Nasrullah, A., Ullah, Z., Sarwono, A., Shah, F.U., Muhammad, N., 2018. Efficient conversion of lignocellulosic biomass to levulinic acid using acidic ionic liquids. Carbohydrate Polymers. 181, 208-214.

42. Kumar, A.K., Sharma, S., 2017. Recent updates on different methods of pretreatment of lignocellulosic feedstocks: a review. Bioresources and Bioprocessing. 4:7.

43. Kumar, P., Barrett, D.M., Delwiche, M.J., Stroeve, P., 2011. Pulsed Electric Field Pretreatment of Switchgrass and Wood Chip Species for Biofuel Production. Ind. Eng. Chem. Res 50, 10996-11001. 
44. Kunaver, M., Jasiukaityte ‘, E., Uk, N.Č., Jasiukaityte, E., Čuk, N., 2012. Ultrasonically assisted liquefaction of lignocellulosic materials. Bioresour. Technol. $103,360-366$.

45. Leskinen, T., Kelley, S.S., Argyropoulos, D.S., 2017. E-beam irradiation \&amp; steam explosion as biomass pretreatment, and the complex role of lignin in substrate recalcitrance. Biomass and Bioenergy 103, 21-28.

46. Li, H., Qu, Y., Yang, Y., Chang, S., Xu, J., 2016a. Microwave irradiation - A green and efficient way to pretreat biomass. Bioresour. Technol. 199, 34-41. https://doi.org/10.1016/j.biortech.2015.08.099

47. Li, J., Dai, J., Liu, G., Zhang, H., Gao, Z., Fu, J., He, Y., Huang, Y., 2016b. Biochar from microwave pyrolysis of biomass: A review. Biomass and Bioenergy 94, 228244.

48. Li, Q., Li, X., Jiang, Y., Xiong, X., Hu, Q., Tan, X., Wang, K., Su, X., 2016 c. Analysis of degradation products and structural characterization of giant reed and Chinese silvergrass pretreated by 60Co- $\gamma$ irradiation. Ind. Crops Prod. 83, 307-315.

49. Liu, X., Hiligsmann, S., Gourdon, R., Bayard, R., 2017. Anaerobic digestion of lignocellulosic biomasses pretreated with Ceriporiopsis subvermispora. Journal of Environmental Management. 193, 154-162.

50. Liu, Y., Guo, L., Wang, L., Zhan, W., Zhou, H., 2017. Irradiation pretreatment facilitates the achievement of high total sugars concentration from lignocellulose biomass. Bioresour. Technol. 232, 270-277.

51. Liu, Y., Zhou, H., Wang, L., Wang, S., Fan, L., 2016. Improving Saccharomyces cerevisiae growth against lignocellulose- derived inhibitors as well as maximizing ethanol production by a combination proposal of c-irradiation pretreatment with in situ detoxification. Chem. Eng. J. 287, 302-312. 
52. Liu, Y., Zhou, H., Wang, S., Wang, K., Su, X., 2015. Comparison of $\gamma$-irradiation with other pretreatments followed with simultaneous saccharification and fermentation on bioconversion of microcrystalline cellulose for bioethanol production. Bioresour. Technol. 182, 289-295.

53. Lo, S.-L., Huang, Y.-F., Chiueh, P.-T., Kuan, W.-H., 2017. Microwave pyrolysis of lignocellulosic biomass. Energy Procedia 105, 41-46.

54. Lopes, A.M., 2014. Ionizing radiation applications for food preservation: effects of gamma and e-beam irradiation on physical and chemical parameters of chestnut fruits. University of Salamanca. $\mathrm{PhD}$ thesis.

55. Luo, J., Fang, Z., Smith, R.L., 2013. Ultrasound-enhanced conversion of biomass to biofuels. Prog. Energy Combust. Sci. 41, 56-93.

56. Madison, M.J., Coward-Kelly, G., Liang, C., Karim, M.N., Falls, M., Holtzapple, M.T., 2017. Mechanical pretreatment of biomass Part I: Acoustic and hydrodynamic cavitation. Biomass and Bioenergy. 98, 135-141.

57. Mante, O.D., Amidon, T.E., Stipanovic, A., Babu, S.P., 2014. Integration of biomass pretreatment with fast pyrolysis: An evaluation of electron beam (EB) irradiation and hot-water extraction (HWE). J. Anal. Appl. Pyrolysis 110, 44-54.

58. Morten Gjermansen, 2014. Biogas From Enzyme-Treated Bagasse. US20140106427A1.

59. Murao, S., Nomura, Y., Yoshikawa, M., Shin, T., Oyama, H., Arai, M., 1992. NIIElectronic Library Service Enhancement of Activities of Cellulases under High Hydrostatic Pressure. Biosci. Biotech. Biochem 56, 1366-1367.

60. Muranaka, Y., Nakagawa, H., Hasegawa, I., Maki, T., Hosokawa, J., Ikuta, J., Mae, K., 2017. Lignin-based resin production from lignocellulosic biomass combining acidic saccharification and acetone-water treatment. Chemical Engineering Journal. 
308, 754-759.

61. North, P.H., 2016. Method and system for fractionation of lignocellulosic biomass. US20160068920 A1.

62. Noparat, P., Prasertsan, P., O-Thong, S., Pang, X., 2017. Sulfite Pretreatment to Overcome Recalcitrance of Lignocellulose for Enzymatic Hydrolysis of Oil Palm trunk. Energy Procedia 138, 1122-1127.

63. Nitsos, C., Rova, U., 2017. Organosolv Fractionation of Softwood Biomass for Biofuel and Biorefinery Applications. Energies 11, 50.

64. Oliveira, S.C.T., Figueiredo, A.B., Evtuguin, D. V, Saraiva, J.A., 2012. High pressure treatment as a tool for engineering of enzymatic reactions in cellulosic fibres. Bioresour. Technol. 107, 530-534.

65. Östergren, K., Gustavsson, J., Hansen, J., Møller, H., Anderson, G., O’Connor, C., Soethoudt, H., Quested, T., Easteal, S., Politano, A., Bellettato, C., Canali, M., Falasconi, L., Gaiani, S., Vittuari, M., Schneider, F., Moates, G., Waldron, K., Redlingshöfer, B., 2014. FUSIONS Definitional Framework for Food Waste. Göteborg.

66. Pielhop, T., Amgarten, J., Von Rohr, R., Studer, M.H., 2016. Steam explosion pretreatment of softwood: the effect of the explosive decompression on enzymatic digestibility. Biotechnol. Biofuels 9: 152.

67. Puértolas, E., Ló Pez, N., Condó, S., Alvarez, I., Raso, J., 2010. Potential applications of PEF to improve red wine quality. Trends Food Sci. Technol. 21, 247-255.

68. Rajendran Velmurugan, K.M., 2012. Ultrasound-assisted alkaline pretreatment of sugarcane bagasse for fermentable sugar production: Optimization through response surface methodology. Bioresour. Technol. 112, 293-299.

69. Ramadoss, G., Muthukumar, K., 2014. Ultrasound assisted ammonia pretreatment of 
sugarcane bagasse for fermentable sugar production. Biochem. Eng. J. 83, 33-41.

70. Ravindran, R., Jaiswal, A., 2016. A Comprehensive Review on Pre-treatment Strategy for Lignocellulosic Food Industry Waste: Challenges and Opportunities. Bioresour. Technol. 199: 92-102.

71. Ravindran, R., Jaiswal, S., Abu-Ghannam, N., Jaiswal, A.K., 2017. Evaluation of Ultrasound Assisted Potassium Permanganate Pre-Treatment of Spent Coffee Waste. Bioresour. Technol. 224, 680-687.

72. Ravindran, R., Jaiswal, S., Abu-Ghannam, N., Jaiswal, A.K., 2018. A comparative analysis of pretreatment strategies on the properties and hydrolysis of brewers' spent grain. Bioresour. Technol. 248, 272-279.

73. Raud, M., Tutt, M., Olt, J., Kikas, T., 2016. Dependence of the hydrolysis efficiency on the lignin content in lignocellulosic material. International Journal of Hydrogen Energy. 41(37), 16338-16343.

74. Romis Consultants Ltd, 2017. Model feasibility study and business plan for ginger processing to oleoresin-an industry wide study report.

75. Saelee, K., Yingkamhaeng, N., Nimchua, T., Sukyai, P., 2016. An environmentally friendly xylanase-assisted pretreatment for cellulose nanofibrils isolation from sugarcane bagasse by high-pressure homogenization. Ind. Crops Prod. 82, 149-160.

76. Saha, B.C., Qureshi, N., Kennedy, G.J., Cotta, M.A., 2016. Biological pretreatment of corn stover with white-rot fungus for improved enzymatic hydrolysis. Int. Biodeterior. Biodegrad. 109, 29-35.

77. Salema, A.A., Ani, F.N., Mouris, J., Hutcheon, R., 2017. Microwave dielectric properties of Malaysian palm oil and agricultural industrial biomass and biochar during pyrolysis Fuel Processing Technology. 166, 164-173.

78. Sampedro, F., Mcaloon, A., Yee, W., Fan, X., Geveke, D.J., 2014. Cost Analysis and 
Environmental Impact of Pulsed Electric Fields and High Pressure Processing in Comparison with Thermal Pasteurization. Food Bioprocess Technol 7, 1928-1937.

79. Sharma, A., Pareek, V., Zhang, D., 2015. Biomass pyrolysis - A review of modelling, process parameters and catalytic studies. Renew. Sustain. Energy Rev. 50, 10811096.

80. Shirkavand, E., Baroutian, S., Gapes, D.J., Young, B.R., 2016. Combination of fungal and physicochemical processes for lignocellulosic biomass pretreatment - A review. Renew. Sustain. Energy Rev. 54, 217-234.

81. Sindhu, R., Binod, P., Pandey, A., 2016. Biological pretreatment of lignocellulosic biomass - An overview. Bioresour. Technol. 199, 76-82.

82. Singh, R., Krishna, B.B., Kumar, J., Bhaskar, T., 2016. Opportunities for utilization of non-conventional energy sources for biomass pretreatment. Bioresour. Technol. 199, $398-407$.

83. Stenmarck, Å., Jensen, C., Quested, T., Moates, G., 2016. Estimates of European food waste levels, 2016th ed. FUSIONS.

84. Subhedar, P.B., Babu, N.R., Gogate, P.R., 2015. Intensification of enzymatic hydrolysis of waste newspaper using ultrasound for fermentable sugar production. Ultrason. Sonochem. 22, 326-332.

85. Subhedar, P.B., Ray, P., Gogate, P.R., 2017. Intensification of delignification and subsequent hydrolysis for the fermentable sugar production from lignocellulosic biomass using ultrasonic irradiation. Ultrason. Sonochem. 40, 140-150.

86. Sun, J.-X., Sun, R., Sun, X.-F., Su, Y., 2004. Fractional and physico-chemical characterization of hemicelluloses from ultrasonic irradiated sugarcane bagasse. Carbohydr. Res. 339, 291-300.

87. Sun, S., Sun, S., Cao, X., Sun, R., 2016. The role of pretreatment in improving the 
enzymatic hydrolysis of lignocellulosic materials. Bioresour. Technol. 199, 49-58.

88. Wood, R.W., Loomis, A.L., 1927. The physical and biological effects of highfrequency sound-waves of great intensity. Philos. Mag. 4, 417-436.

89. Xiang, Y., Xiang, Y., Wang, L., 2017. Electron beam irradiation to enhance enzymatic saccharification of alkali soaked Artemisia ordosica used for production of biofuels. J. Environ. Chem. Eng. 5, 4093-4100.

90. Xing, X., Wenhua, G., Jiming, X., Shouyong, Z., Yijiang, Z., Jun, X., Xiaoyan, L., 2017. Method for improving lignocellulose enzymolysis efficiency by lignocellulose pretreatment through ultrasonic-microwave synchronously-assisted ionic liquid system. CN106591395A.

91. Xu, Q.Q., Zhao, M.J., Yu, Z.Z., Yin, J.Z., Li, G.M., Zhen, M.Y., Zhang, Q.Z., 2017. Enhancing enzymatic hydrolysis of corn cob, corn stover and sorghum stalk by dilute aqueous ammonia combined with ultrasonic pretreatment. Ind. Crops Prod. 109, 220226.

92. Yang, S.J., Yoo, H.Y., Choi, H.S., Lee, J.H., Park, C., Kim, S.W., 2015. Enhancement of enzymatic digestibility of Miscanthus by electron beam irradiation and chemical combined treatments for bioethanol production. Chem. Eng. J. 275, 227-234.

93. Yoo, C.G., Pu, Y., Ragauskas, A.J., Turner, C., Wang, J., 2017. Ionic liquids: Promising green solvents for lignocellulosic biomass utilization. Curr. Opin. Green Sustain. Chem. 5, 5-11.

94. Yu, J., Paterson, N., Blamey, J., Millan, M., 2017. Cellulose, xylan and lignin interactions during pyrolysis of lignocellulosic biomass. Fuel 191, 140-149.

95. Zhang, C., Su, X., Xiong, X., Hu, Q., Amartey, S., Tan, X., Qin, W., 2016a. 60Co- $\gamma$ radiation-induced changes in the physical and chemical properties of rapeseed straw. Biomass and Bioenergy 85, 207-214. 
96. Zhang, C.-W., Xia, S.-Q., Ma, P.-S., 2016b. Facile pretreatment of lignocellulosic biomass using deep eutectic solvents. Bioresource Technology. 219, 1-5.

97. Zhang, Z., Xie, Y., He, X., Li, X., Hu, J., Ruan, Z., Zhao, S., Peng, N., Liang, Y., 2016c. Comparison of high-titer lactic acid fermentation from $\mathrm{NaOH}-$ and $\mathrm{NH} 3-\mathrm{H} 2$ O 2 -pretreated corncob by Bacillus coagulans using simultaneous saccharification and fermentation. Scientific Reports. 6, 37245.

98. Zhang, Y.Q., Fu, E.H., Liang, J.H., 2008. Effect of Ultrasonic Waves on the Saccharification Processes of Lignocellulose. Chem. Eng. Technol. 31, 1510-1515.

99. Zhou, H., Zhang, R., Zhan, W., Wang, L., Guo, L., Liu, Y., 2016. High biomass loadings of $40 \mathrm{wt} \%$ for efficient fractionation in biorefineries with an aqueous solvent system without adding adscititious catalyst. Green Chem. 18, 6108-6114.

100. Zhuang, X., Wang, W., Yu, Q., Qi, W., Wang, Q., Tan, X., Zhou, G., Yuan, Z., 2016. Liquid hot water pretreatment of lignocellulosic biomass for bioethanol production accompanying with high valuable products. Bioresource Technology. 199, $68-75$. 
Table 1. Chemical composition of different lignocellulosic feedstocks (\% dry basis)

\begin{tabular}{|c|c|c|c|c|}
\hline Source & Cellulose & Hemicellulose & Lignin & References \\
\hline \multicolumn{5}{|l|}{ Hardwood } \\
\hline Eucalyptus & 44.9 & 28.9 & 26.2 & (Muranaka et al., 2017) \\
\hline Oak & 43.2 & 21.9 & 35.4 & $(\mathrm{Yu}, 2017)$ \\
\hline Rubber wood & 39.56 & 28.42 & 27.58 & (Khan et al., 2018) \\
\hline \multicolumn{5}{|l|}{ Softwood } \\
\hline Spruce & 47.1 & 22.3 & 29.2 & $(\mathrm{Yu}, 2017)$ \\
\hline Pine & 45.6 & 24.0 & 26.8 & $(\mathrm{Yu}, 2017)$ \\
\hline Japanese cedar & 52.7 & 13.8 & 33.5 & (Muranaka et al., 2017) \\
\hline \multicolumn{5}{|l|}{ Grasses } \\
\hline Bamboo & 46.5 & 18.8 & 25.7 & (Chen et al., 2017) \\
\hline Amur silver-grass & 42.00 & 30.15 & 7.00 & (Raud et al., 2016) \\
\hline Natural hay & 44.9 & 31.4 & 12.0 & $\begin{array}{l}\text { (De Caprariis et al., } \\
2017 \text { ) }\end{array}$ \\
\hline Hemp & 53.86 & 10.60 & 8.76 & (Raud et al., 2016) \\
\hline Rye & 42.83 & 27.86 & 6.51 & (Raud et al., 2016) \\
\hline Reed & 49.40 & 31.50 & 8.74 & (Raud et al., 2016) \\
\hline Sunflower & 34.06 & 5.18 & 7.72 & (Raud et al., 2016) \\
\hline Silage & 39.27 & 25.96 & 9.02 & (Raud et al., 2016) \\
\hline Szarvasi-1 & 37.85 & 27.33 & 9.65 & (Raud et al., 2016) \\
\hline \multicolumn{5}{|l|}{$\begin{array}{l}\text { Agroindustrial } \\
\text { waste }\end{array}$} \\
\hline Walnut shell & 23.3 & & 53.5 & $\begin{array}{l}\text { (De Caprariis et al., } \\
\text { 2017) }\end{array}$ \\
\hline Groundnut shell & 37 & 18.7 & 28 & (Subhedar et al, 2017) \\
\hline Pistachio shell & 15.2 & 38.2 & 29.4 & (Subhedar et al, 2017) \\
\hline Almond shell & 27 & 30 & 36 & (Álvarez et al., 2018) \\
\hline Pine nut shell & 31 & 25 & 38.0 & (Álvarez et al., 2018) \\
\hline Hazelnut shell & 30 & 23 & 38.0 & (Álvarez et al., 2018) \\
\hline Coconut coir & 44.2 & 22.1 & 32.8 & (Subhedar et al, 2017) \\
\hline Cotton stalk & 67 & 16 & 13 & (Kim et al., 2016) \\
\hline Hemp stalk & 52 & 25 & 17 & (Kim et al., 2016) \\
\hline Acacia pruning & 49 & 13 & 32 & (Kim et al., 2016) \\
\hline Sugarcane peel & 41.11 & 26.40 & 24.31 & (Huang et al., 2016b) \\
\hline Rice husk & 40 & 16 & 26 & (Daza Serna et al., 2016) \\
\hline Rice straw & 38.14 & 31.12 & 26.35 & (Huang et al., 2016b) \\
\hline Barley straw & 35.4 & 28.7 & 13.1 & (Liu et al., 2017) \\
\hline Coffee grounds & 33.10 & 30.03 & 24.52 & (Huang et al., 2016b) \\
\hline $\begin{array}{l}\text { Extracted olive } \\
\text { pomace }\end{array}$ & 19 & 22 & 40.0 & (Álvarez et al., 2018) \\
\hline Palm oil frond & 37.32 & 31.89 & 26.05 & (Khan et al., 2018) \\
\hline Corn stover & 43.97 & 28.94 & 21.82 & (Huang et al., 2016b) \\
\hline Bamboo leaves & 34.14 & 25.55 & 35.03 & (Huang et al., 2016b) \\
\hline Hazel branches & 30.8 & 15.9 & 19.9 & (Liu et al., 2017) \\
\hline
\end{tabular}


Table 2. Major advantages and disadvantages of each of the common pretreatment methods

\begin{tabular}{|c|c|c|c|c|}
\hline Pretreatment Method & Effects & Advantage & Disadvantage & References \\
\hline Mechanical Milling & $\begin{array}{l}\text { Reduce the particle size } \\
\text { and crystallinity of } \\
\text { lignocellulosic materials }\end{array}$ & $\begin{array}{l}\text { Control of final } \\
\text { particle size, Make } \\
\text { handling of material } \\
\text { easy }\end{array}$ & $\begin{array}{l}\text { High energy } \\
\text { consumption }\end{array}$ & $\begin{array}{l}\text { (Devendra et al., } \\
\text { 2015) }\end{array}$ \\
\hline Extrusion & $\begin{array}{l}\text { Shortening of fiber and } \\
\text { defibrillation }\end{array}$ & $\begin{array}{l}\text { operate at high } \\
\text { solids loadings, low } \\
\text { production of } \\
\text { inhibitory } \\
\text { compounds, short } \\
\text { time }\end{array}$ & $\begin{array}{l}\text { High energy } \\
\text { consumption, effect is } \\
\text { limited when no } \\
\text { chemical agents are } \\
\text { used, mostly effective } \\
\text { on herbaceous type } \\
\text { biomass }\end{array}$ & $\begin{array}{l}\text { (Duque et al., } \\
\text { 2017) }\end{array}$ \\
\hline Acid & $\begin{array}{l}\text { Hemicellulose and lignin } \\
\text { fractionation }\end{array}$ & $\begin{array}{l}\text { Enzymatic } \\
\text { hydrolysis is } \\
\text { sometimes not } \\
\text { required as the acid } \\
\text { itself may } \\
\text { hydrolyses the } \\
\text { biomass to yield } \\
\text { fermentable sugars }\end{array}$ & $\begin{array}{l}\text { High cost of the } \\
\text { reactors, chemicals are } \\
\text { corrosive and toxic, } \\
\text { and formation of } \\
\text { inhibitory by-products }\end{array}$ & $\begin{array}{l}\text { (Jönsson and } \\
\text { Martín, 2016) }\end{array}$ \\
\hline Alkaline & $\begin{array}{l}\text { Lignin and hemicelluloses } \\
\text { removal }\end{array}$ & $\begin{array}{l}\text { Cause less sugar } \\
\text { degradation than } \\
\text { acid pretreatment }\end{array}$ & $\begin{array}{l}\text { Generation of } \\
\text { inhibitors }\end{array}$ & $\begin{array}{l}\text { (Zhang et al., } \\
\text { 2016c) }\end{array}$ \\
\hline Organosolv & $\begin{array}{l}\text { Lignin removal and } \\
\text { hemicellulose } \\
\text { fractionation }\end{array}$ & $\begin{array}{l}\text { Produce low residual } \\
\text { lignin substrates that } \\
\text { reduce unwanted } \\
\text { adsorption of } \\
\text { enzymes and allows } \\
\text { their recycling and } \\
\text { reuse. }\end{array}$ & $\begin{array}{l}\text { High capital } \\
\text { investment, Handling } \\
\text { of harsh organic } \\
\text { solvents, formation of } \\
\text { inhibitors }\end{array}$ & $\begin{array}{l}\text { (Nitsos and } \\
\text { Rova, 2017) }\end{array}$ \\
\hline Oxidation & $\begin{array}{l}\text { Removal of lignin and } \\
\text { hemicelluloses }\end{array}$ & $\begin{array}{l}\text { Lower production of } \\
\text { by products }\end{array}$ & $\begin{array}{l}\text { Cellulose is partly } \\
\text { degraded, High cost }\end{array}$ & $\begin{array}{l}\text { (Chandel and da } \\
\text { Silva, 2013) }\end{array}$ \\
\hline Ionic liquid & $\begin{array}{l}\text { Cellulose crystallinity } \\
\text { reduction and partial } \\
\text { hemicellulose and lignin } \\
\text { removal }\end{array}$ & $\begin{array}{l}\text { low vapor pressure } \\
\text { designer solvent, } \\
\text { working under mild } \\
\text { reaction conditions }\end{array}$ & $\begin{array}{l}\text { Costly, complexity of } \\
\text { synthesis and } \\
\text { purification, toxicity, } \\
\text { poor biodegrability } \\
\text { and inhibitory effects } \\
\text { on enzyme activity }\end{array}$ & $\begin{array}{l}\text { (Yoo et al., } \\
2017 \text { ) }\end{array}$ \\
\hline Liquid Hot Water & $\begin{array}{l}\text { Removal of soluble lignin } \\
\text { and Hemicellulose }\end{array}$ & $\begin{array}{l}\text { The residual lignin } \\
\text { put a negative effect } \\
\text { on the subsequent } \\
\text { enzymatic } \\
\text { hydrolysis }\end{array}$ & $\begin{array}{l}\text { High water } \\
\text { consumption and } \\
\text { energy input }\end{array}$ & $\begin{array}{l}\text { (Zhuang et al., } \\
\text { 2016) }\end{array}$ \\
\hline AFEX & Lignin removal & $\begin{array}{l}\text { High efficiency and } \\
\text { selectivity for } \\
\text { reaction with lignin }\end{array}$ & $\begin{array}{l}\text { It is much less } \\
\text { effective for softwood, } \\
\text { Cost of ammonia and } \\
\text { its environmental } \\
\text { concerns }\end{array}$ & (Bajpai, 2016) \\
\hline SPORL & Lignin removal & $\begin{array}{l}\text { Effective against } \\
\text { hardwood and } \\
\text { softwood, and } \\
\text { energy efficient }\end{array}$ & $\begin{array}{l}\text { Pretreatment is } \\
\text { preceded by biomass } \\
\text { size-reduction }\end{array}$ & $\begin{array}{l}\text { (Noparat et al., } \\
\text { 2017) }\end{array}$ \\
\hline
\end{tabular}


Table 3. Major advantages and disadvantages of selected green chemistry pretreatment methods.

\begin{tabular}{|c|c|c|c|c|}
\hline Pretreatment Methods & Effects & Advantage & Disadvantage & References \\
\hline Deep eutectic solvents & $\begin{array}{l}\text { lignin removal } \\
\text { and } \\
\text { hemicellulose } \\
\text { fractionation }\end{array}$ & $\begin{array}{l}\text { Green solvent, } \\
\text { biodegradable } \\
\text { and } \\
\text { biocompatible }\end{array}$ & $\begin{array}{l}\text { Poor Stability } \\
\text { under higher } \\
\text { pretreatment } \\
\text { temperatures, }\end{array}$ & $\begin{array}{l}\text { (Zhang et al., } \\
\text { 2016b) }\end{array}$ \\
\hline Steam Explosion & $\begin{array}{l}\text { lignin } \\
\text { softening, } \\
\text { particle size } \\
\text { reduction }\end{array}$ & $\begin{array}{l}\text { low capital } \\
\text { investment, } \\
\text { moderate energy } \\
\text { requirements } \\
\text { and low } \\
\text { environmental } \\
\text { impacts }\end{array}$ & $\begin{array}{l}\text { It is much less } \\
\text { effective for } \\
\text { softwood }\end{array}$ & $\begin{array}{l}\text { (Pielhop et } \\
\text { al., 2016) }\end{array}$ \\
\hline Supercritical fluids & $\begin{array}{l}\text { Cellulose } \\
\text { crystallinity } \\
\text { reduction and } \\
\text { lignin removal }\end{array}$ & $\begin{array}{l}\text { Green solvent is } \\
\text { used, it does not } \\
\text { cause } \\
\text { degradation of } \\
\text { sugars, method } \\
\text { is suitable for } \\
\text { mobile biomass } \\
\text { processor }\end{array}$ & $\begin{array}{l}\text { Total utilities } \\
\text { costs are high }\end{array}$ & $\begin{array}{l}\text { (Daza Serna } \\
\text { et al., 2016) }\end{array}$ \\
\hline Microbes & $\begin{array}{l}\text { Lignin and } \\
\text { hemicellulose } \\
\text { degradation }\end{array}$ & $\begin{array}{l}\text { Environment } \\
\text { friendly, } \\
\text { selective } \\
\text { degradation of } \\
\text { lignin and } \\
\text { hemicelluloses }\end{array}$ & $\begin{array}{l}\text { Very long } \\
\text { pretreatment time } \\
\text { (several weeks) } \\
\text { due to slow yield }\end{array}$ & $\begin{array}{l}\text { (Sun et al., } \\
2016)\end{array}$ \\
\hline
\end{tabular}




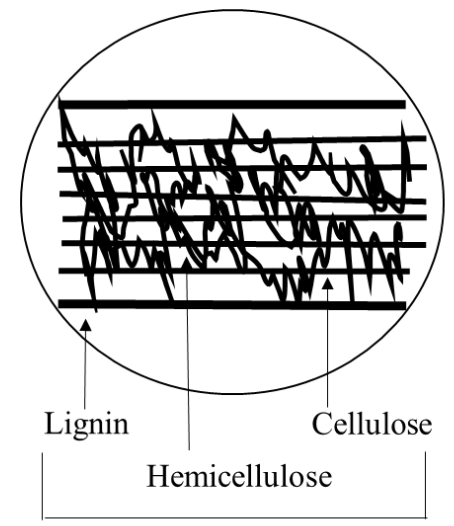

Lignocellulose Biomass before Pretreatment

\section{Pretreatment of Lignocellulosic biomass using Emerging Technologies}

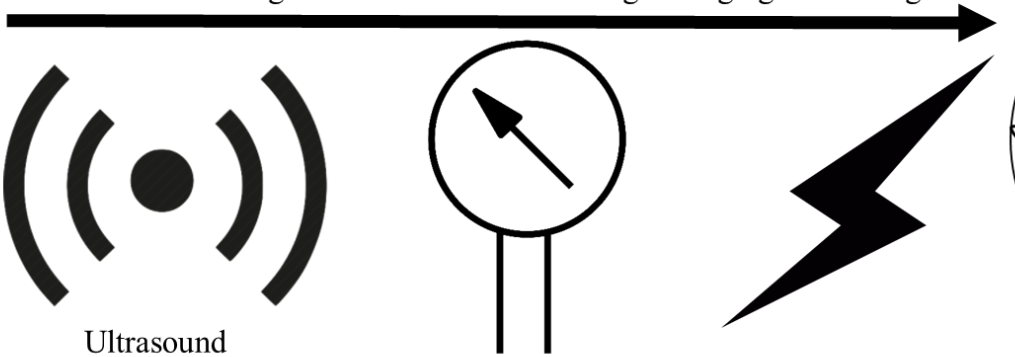

Microwave

High hydrostatic pressure

pulsed-electric field

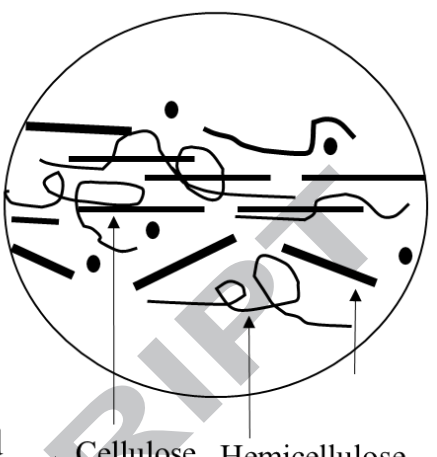

Cellulose Hemicellulose Electron beam

High pressure homogenization

Emerging Technologies for pretreatment of Lignocellulosic biomass 


\section{Highlights}

- Conventional pretreatment methods of lignocellulose suffer significant disadvantages.

- Non-thermal food processing technologies investigated as emerging pretreatments.

- Emerging technologies are promising candidates as sustainable green pretreatments.

- Comparative and feasibility studies are required for the emerging pretreatments. 